\title{
Conflicting Strategies of Management and Memory at the Indiana Roof Ballroom, 1933-34 ${ }^{1}$
}

\author{
C. Matthew Balensuela
}

The Indiana Roof Ballroom in downtown Indianapolis houses a unique and largely unstudied artifact on the reception of jazz and popular music in the early 1930s. From 1933 to 1936, two stagehands wrote the names of bands that played at the Roof on the door of a storeroom giving a rating of one to four stars (fair to extraordinary) for each band (see Figure 1). The "Jazz Door" (as it is called) is currently displayed by the stage entrance of the Ballroom with a commemorative brass plaque, which explains that the door was the work of two employees of the Roof, John Young and Tom Kelly, and describes the door as a faithful record of early jazz criticism.

This paper is the first scholarly examination of the Jazz Door and will compare the entries on the Door for the 1933-34 season with ticket prices and publicity for the Ballroom, as seen in the local newspapers. ${ }^{2}$ This study demonstrates that the creators of the Jazz Door and the management of the Indiana Roof Ballroom had differing opinions on the roles and purposes of popular music. These differences explain a number of obscure and unusual entries on the Door and demonstrate that the Roof Ballroom presented more than just the bands listed on the Jazz Door. In seeking to explain these differences, this paper views the Jazz Door not only as a record of jazz criticism, but seeks to place the Door within the larger contexts of society and commerce at the height of the Depression.

\footnotetext{
${ }^{1}$ Earlier versions of this paper were presented to the American Musicological Society Annual Meeting, November 11, 2011 and also at Indiana University, Butler University, Eastern Illinois University, and DePauw University. This research has been supported by grants from the Great Lakes Colleges Association's New Directions Initiative and DePauw University's Professional Development Fund. The author would like to thank Thomas J. Mathiesen, Jeffrey Magee, and Kenneth Prouty for their criticisms of earlier drafts of this essay.

${ }^{2}$ The author intends to continue the study of the other two seasons listed on the Jazz Door (1934-35 and 1935-36) in future research.
} 


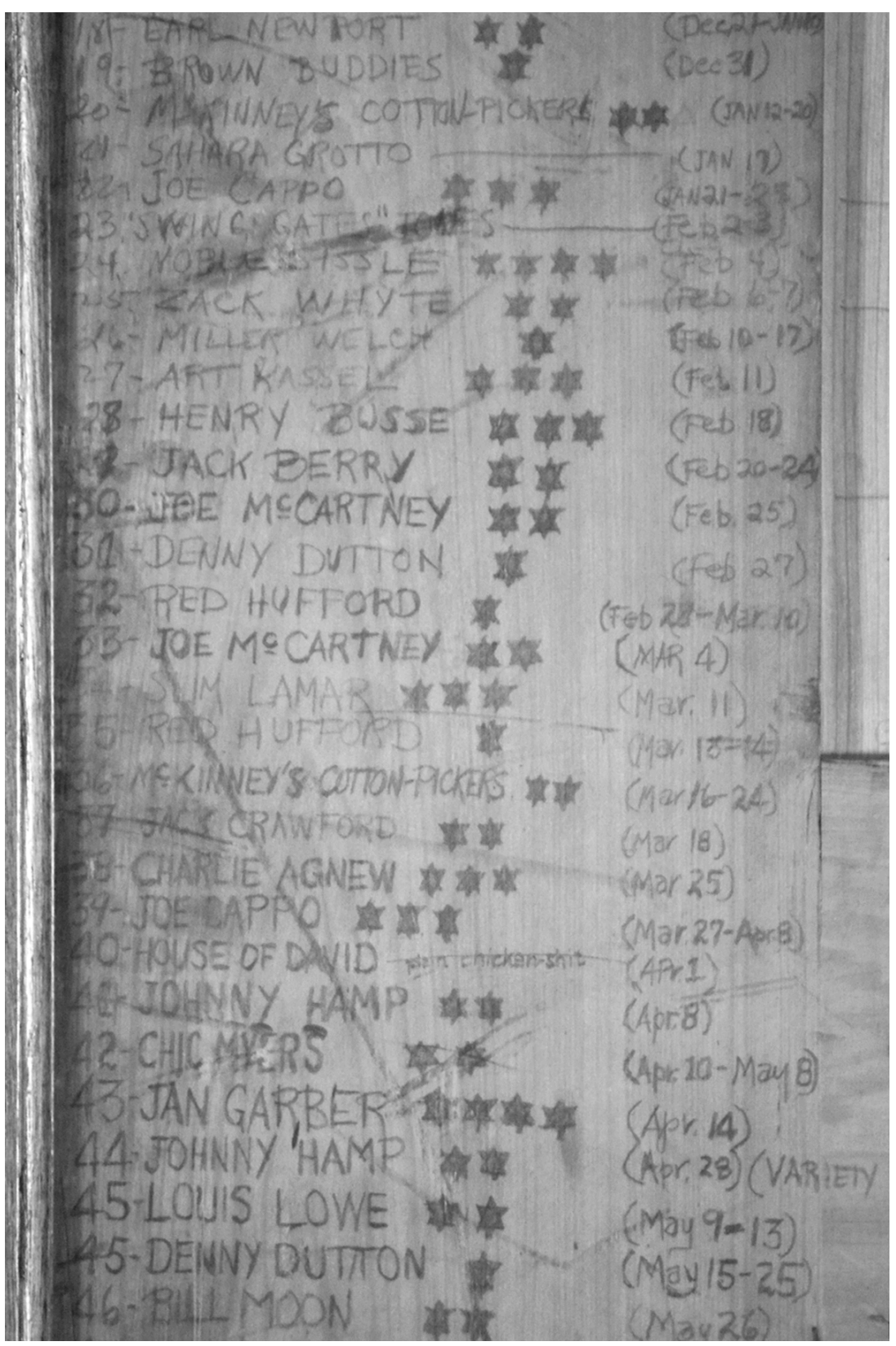

Figure 1. Left section of the Jazz Door at the Indiana Roof Ballroom (December 21, 1933May 26, 1934). Photograph by Marilyn Culler.

STRATEGIES OF MEMORY: THE JAZZ DOOR FOR 1933-34

Indianapolis is not often cited as an important city for jazz and dance music in the 1920s or 1930s. Despite its size and proximity to such jazz 
centers as Chicago and Saint Louis, Indianapolis's musical history is relatively unstudied in the early twentieth century. ${ }^{3}$ Jazz historians have focused on other Indiana institutions and cities in the early history of jazz-most notably Gennett Records in Richmond, which recorded some of the earliest jazz records. ${ }^{4}$ As for Indianapolis itself, most attention has been paid to the musicians associated with the nightclubs on Indiana Avenue in the 1940s and 1950s such as Wes Montgomery, Slide Hampton, and David Baker. ${ }^{5}$

The Indiana Roof Ballroom (hereafter IRB) opened in September 1927 on the top floor of the Indiana Theatre. ${ }^{6}$ The exterior of the building is in a Spanish Baroque style, and the Ballroom's interior depicts the plaza of a Spanish village with stucco facades and balconies with ornate railings. ${ }^{7}$

Soon after the IRB opened, staff and visitors began to write or carve graffiti-mostly just a name and date-on the interior side of the dressing

${ }^{3}$ The major monograph on jazz history in the state is Duncan Scheidt's The Jazz Sate of Indiana (Pittsboro, IN: self published, 1977); reprint ed. (Indianapolis: Indiana Historical Society, 1999). See also Russell W. Archer, "If These Walls could Jump 'n' Jive: A Study of Buildings and Sites Associated with Jazz Music in Indianapolis and Richmond, Indiana (c. 1910-1960)," MS Thesis, Ball State University, 2003.

${ }^{4}$ Rick Kennedy, Jelly Roll, Bix, and Hoagy: Gennett Studios and the Birth of Recorded Jazz (Bloomington: Indiana University Press, 1994).

${ }^{5}$ David Leander Williams, Indianapolis Jazz: The Masters, Legends and Legacy of Indiana Avenue (Charleston, SC: History Press, 2014) and Monika Herzig, ed., David Baker: A Legacy in Music (Bloomington: Indiana University Press, 2011). See also Amy H. Wilson, "The Swing Era on Indiana Avenue: A Cultural History of Indianapolis' AfricanAmerican Jazz Scene, 1933-1950.” MA Thesis, Indiana University, 1997.

${ }^{6}$ Located at 140 West Washington Street, the IRB is near the center of downtown Indianapolis. Other studies of specific ballrooms include Andrew Berish, "Swinging Transcontinental: Modernity, Race, and Place in American Dance Band Music, 1930 to 1946," PhD, Musicology, University of California at Los Angeles, 2005; Andrew Berish, "I Dream of Her and Avalon': 1930s Sweet Jazz, Race, and Nostalgia at the Casino Ballroom," Journal of the Society for American Music 2, no. 4 (2008): 531-67; Lisa Doolittle, "The Trianon and On: Reading Mass Social Dancing in the 1930s and 1940s in Alberta, Canada," in Julie Malnig, ed. Ballroom, Boogie, Shimmy Sham, Shake: A Social and Popular Dance Reader, 109-25 (Urbana: University of Illinois Press, 2009); Barbara Engelbrecht, "Swinging at the Savoy," Dance Research Journal 15, no. 2 (Spring 1983): 310; Karen Hubbard and Terry Monaghan, "Negotiating Compromise on a Burnished Wood Floor: Social Dancing at the Savoy," in Malnig, ed. Ballroom, Boogie, Shimmy Sham, Shake, 126-45; and Patrice Madura Ward-Steinman, Madura's Danceland, Images of America (Charleston, SC: Arcadia, 2010).

${ }^{7}$ The theatre was designed by Preston C. Rubush and Edgar O. Hunter, local architects who also designed the Circle Theatre in Indianapolis. Howard Caldwell, The Golden Age of Indianapolis Theatres (Bloomington, IN: Quarry Books, 2010) and the Roof's own website at http://www.indianaroof.com/. 
room door on the second floor. Included on the left side of the door is an earlier version of Kelly and Young's later Jazz Door, what might be called the "First Door." (see Figure 2). Tom Kelly was a student at Butler University, who worked as stagehand starting in June 1928, whose life after his work at the IRB is currently unknown. ${ }^{8}$ John Young worked as a porter at the IRB starting in October 1927 (soon after it opened) and went on to work in the Human Resources department of International Harvester. In 1929 the two began a record of the performers at the Ballroom on this dressing room door using the same system of stars seen later in the Jazz Door. Kelly and Young drew attention to themselves not only by signing both doors, but by also altering their names on each: on the First Door they gave themselves Spanish titles (Señore[s]) and on the Jazz Door, they purposefully misspelled their names (Jhon and Thom). Showing their sense of humor, they rated themselves with five stars at the end of the 1933-34 season; the highest rating of any band is only four (see end of Figure 3).

In the earliest season chronicled on the First Door (1929-30) Kelly and Young recorded the appearances of such bands as McKinney's Cotton Pickers (***), Goldkette's Vagabonds (**), and Indianapolis native Charlie Davis (\$), but without giving specific dates. ${ }^{9}$ As their enumeration was written on a public door, their list was altered by other writers that crowded out the order they sought to establish. The following seasons have successively fewer names and are clearly not complete. In the 1930-31 season only eight names are listed, without star ratings; the most familiar band in this list is the Paul Whiteman Orchestra. Another list on the dressing room door is undated, but is probably for the 1932-33 season and includes Fletcher Henderson $(* *$ ).

\footnotetext{
${ }^{8}$ David Mannweiler, "Fabled Jazz Door Critics Unmasked," Indianapolis Nerws, August 29, 1986 and "The Jazz Doors," Indianapolis Magazine November, 1986, 40.

${ }^{9}$ Kelly and Young consistently use a six-pointed star on the Jazz Door. There is no evidence that the shape carries any spiritual or religious meaning. It may have been easier to draw two interlocking triangles consistently than it would be to draw a five-pointed star.
} 


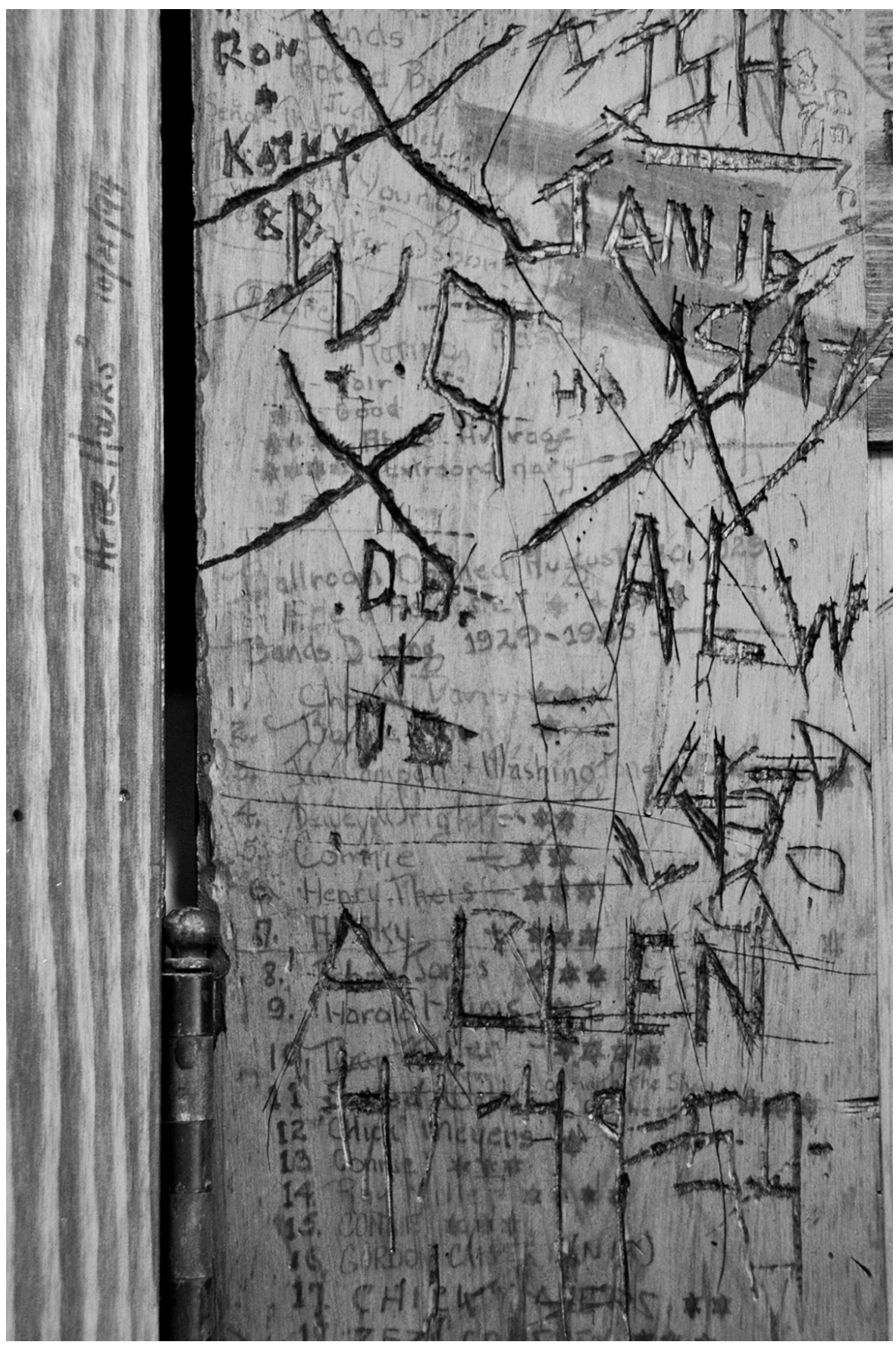

Figure 2. Left side, middle section of the dressing room door or First Door detailing 1929-30 season. Photograph by Marilyn Culler. 
At the start of the 1933-34 season, Kelly and Young took up their systematic evaluation of the bands in another, less public space-the interior door of a storage room that only workers at the Roof had access to (see Figure 3). In their new list, Kelly and Young, not only gave a star rating for each band and numbered each appearance (as they had on the First Door), but also gave specific dates and noted when the Roof was rented to other organizations in the "margins." 10 Thus a number of entries list the band with a marginal note of groups that rented the ballroom, such as the Forty and Eight Society (a World War I veterans group) on February 24th, or the Young Republicans at the end of the season on June 9th.

Kelly and Young's systematic attempt to document every performer at the Roof is an unusual use of graffiti. They do not just note the most famous bands or special occasions, but appear to chronicle the day-to-day events of the Ballroom. As a result, their writing can be seen as an attempt to create a historical record-a strategy of memory-that would preserve their view of the activities at the Roof. ${ }^{11}$

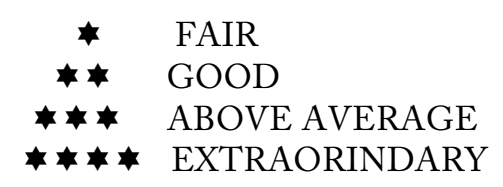

Rated by Jhon + Tohm 1933-1934

$\begin{array}{lll}\text { 1-FRANKIE TRUMBAUER } & \star \star & (\text { SEPT 15-27) } \\ \text { 2-BERNIE YOUNG } & & \text { (SEPT 29-30) } \\ \text { 3-BUDDY ROGERS } & \star \star & \text { (OCT 1) } \\ \text { 4-SLIM LAMAR } & \star \star & \text { (OCT 4-6) } \\ \text { 5-TED MACK } & \star \star & \text { (OCT 7-22) } \\ \text { 6-PERCY CARSON } & \star \star & \text { (OCT 24-27) } \\ \text { 7-LOUIE PANICO } & \star \star & \text { (OCT 28-29) } \\ \text { 8-PERCY CARSON } & \star \star & \text { (OCT 31-NOV 4) }\end{array}$

${ }^{10}$ This started only after they placed the Sahara Grotto (a local fraternal organization similar to the Masons) within the list but with no stars on January 17, 1934.

${ }_{11}$ Another "historic" door was created in the early 1920s at Frank Shay's Greenwich Village Bookshop in New York City, which features the signatures of 242 authors. The door is in the collection of the Harry Ransom Center of the University of Texas at Austin and is described at "The Greenwich Village Bookshop Door: A Portal to Bohemia, 19201925," http://research.hrc.utexas.edu/bookshopdoor/\#1. In jazz, "The Famous Door" was a club located at various places on West 52nd Street in New York City from 1935-50 and was the recording location for Count Basie Live! 1938 at the Famous Door NYC, reissued by Jazz Hour, CD B000003LXZ (1997). There is also a restaurant in the French Quarter of New Orleans named "The Famous Door." 


\begin{tabular}{|c|c|c|c|}
\hline 9-HERBIE KAY & $\star \star \star \star$ & (NOV 5) & \\
\hline 10-PERCY CARSON & $\star \star$ & (NOV 7-11) & \\
\hline 11-PAUL SPECHT & $\star \star$ & (NOV 12) & \\
\hline 12-EARL NEWPORT & $*$ & (NOV 14-18) & \\
\hline 13-RALPH BENNETT & $\star \star \star *$ & (NOV 19) & \\
\hline 14-EARL NEWPORT & $\star$ & (NOV 21-29) & \\
\hline $\begin{array}{l}\text { 15-CALIFORNIA } \\
\text { SYNCOPATORS }\end{array}$ & $\star *$ & $(\mathrm{NOV} 30)$ & \\
\hline 16-EARL NEWPORT & $\star \star$ & (DEC 1-19) & \\
\hline \multicolumn{4}{|c|}{ (STREETS OF PARIS-DEC 1-8) } \\
\hline $\begin{array}{l}\text { 17-FLETCHER } \\
\text { HENDERSON }\end{array}$ & $\star \star$ & $(\mathrm{DEC} 20)$ & \\
\hline 18-EARL NEWPORT & $\star \star$ & (DEC 21-JAN 10) & \\
\hline 19-BROWN BUDDIES & $\star$ & (DEC 31) & \\
\hline $\begin{array}{l}\text { 20-M'KINNEY'S COTTON } \\
\text { PICKERS }\end{array}$ & $\star \star$ & (JAN 12-20) & \\
\hline 21-SAHARA GROTTO & - & (JAN 17) & \\
\hline 22-JOE CAPPO & $\star \star \star$ & (JAN 21-25) & $\begin{array}{l}\text { Hardware } \\
\text { Convention (JAN 29- } \\
\text { 30-31-Feb 1) }\end{array}$ \\
\hline 23-“SWING GATES” JONES & - & (FEB 2-3) & \\
\hline 24-NOBLE SISSLE & $\star \star \star *$ & (FEB 4) & \\
\hline 25-ZACK WHYTE & $\star \star$ & (FEB 6-7) & $\underset{8-9)}{-F l o w e r ~ S h o w ~(F e b ~}$ \\
\hline 26-MILLER WELCH & $\star$ & (FEB 10-17) & \\
\hline 27-ART KASSEL & $\star * *$ & (FEB 11) & \\
\hline 28-HENRY BUSSE & $\star \star \star$ & (FEB 18) & \\
\hline 29-JACK BERRY & $\star \star$ & (Feb 20-24) & $-40 \& 8$ (Feb 24) \\
\hline 30-JOE MCARTNEY & $\star \star$ & $(\mathrm{Feb} 25)$ & \\
\hline 31-DENNY DUTTON & $\star$ & $($ feb 27) & \\
\hline 32-RED HUFFORD & $\star$ & (Feb 28-Mar. 10) & \\
\hline 33-JOE MCARTNEY & ** & (MAR 4) & \\
\hline 34-SLIM LAMAR & *** & (Mar. 11) & \\
\hline 35-RED HUFFORD & $\star$ & (Mar 13-14) & \\
\hline 36-M'KINNEY'S COTTON & $\star *$ & (Mar 16-24) & \\
\hline PICKERS & & & \\
\hline 37-JACK CRAWFORD & $\star *$ & (Mar 18) & \\
\hline 38-CHARLIE AGNEW & $\star * *$ & (Mar 25) & \\
\hline 39-JACK [[JOE]] CAPPO & $\star \star \star$ & (Mar 27-Apr 8) & \\
\hline 40-HOUSE OF DAVID & plain chicken-shit & (Apr 1) & \\
\hline 41-JOHNNY HAMP & $\star \star$ & (Apr. 8) & \\
\hline 42-CHIC MYERS & $\star \star$ & (Apr. 10-May 8) & \\
\hline 43-JAN GARBER & 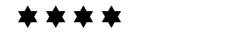 & (Apr. 14) & \\
\hline 44-JOHNNY HAMP & $\star \star$ & (Apr. 28) & (VARIETY CLUB) \\
\hline 45-LOUIS LOWE & $\star \star$ & (May 9-13) & \\
\hline 45 [[46]]--DENNY & $\star$ & (May 15-25) & \\
\hline DUTTON & & & \\
\hline 46 [[47]]-BILL MOON & $\star \star$ & (May 26) & \\
\hline $\begin{array}{c}47[[48]]-\text { CHIC MEYERS } \\
\text { [[MYERS }]]\end{array}$ & $\star$ & (May 27-29) & \\
\hline 47 [[49]]-BILL MOON & $\star \star$ & (May 30-June1) & \\
\hline 48 [[50]]-NOBLE SISSLE & $* * *$ & (June 2) & \\
\hline
\end{tabular}


49 [[51]]-BILL MOON 50 [[52]] JACK TILSON John Tom

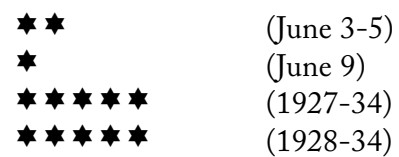

YOUNG REP CLUB

Figure 3. Diplomatic Transcription of the "Jazz Door" at the Indiana Roof Ballroom, 1933-34 section. Annotations by the editor are in double square brackets [[ ]].

\section{INTERPRETING THE DOOR}

For jazz historians, the names of the well-known figures on the IRB's Jazz Door, such as Fletcher Henderson (December 20), jump out from more obscure names, such as Earl Newport or "Swing Gates" Jones. For these famous performers, the Jazz Door can fill in missing details. For example, the Jazz Door can modestly supplement Walter Allen's magisterial biodiscography of Fletcher Henderson, Hendersonia: The Music of Fletcher Henderson and His Musicians, and Jeffrey Magee's 2004 biography, The Uncrowned King of Swing: Fletcher Henderson and Big Band Jazz. While detailing Henderson's activities in late 1933, Allen lists, "Tour, onenighters, until the end of year. Known engagements in Indianapolis, Cleveland, and Kansas City." On December 13, Allen places the band in Nashville, and the next specific entry is December 22 in Lansing, Michigan. ${ }^{12}$ The Door places Henderson at the IRB between these jobs on Wednesday, December 20th. The rating of only two stars seems to support Jeffrey Magee's description of the Henderson band at the time: "From 1932 to 1934, indeed, the band's fortunes were mixed, partly due to circumstances beyond Henderson's control, and partly due to the band's increasingly casual approach to securing and keeping employment."13

The bands with the highest ratings also grab one's attention. Figure 4 arranges the names on the Door from highest to lowest rating for the 1933-34 season, cross references those appearances with each time a band's name appears on the Door up to June 1936, and calculates how many performances a band gave over that period. Jan Garber is known today for the sweet jazz style-danceable arrangements of popular tunes with little improvisation-and his performances were clearly appreciated by the Door's scribes, perhaps representing their ideal of good music. Garber is the only musician to get a top rating for every appearance from

\footnotetext{
${ }^{12}$ Walter C. Allen, Hendersonia: The Music of Fletcher Henderson and His Musicians, Jazz Monographs 4 (Highland Park, NJ: Walter C. Allen, 1973), 306.

${ }^{13}$ Jeffrey Magee, The Uncrowned King of Swing: Fletcher Henderson and Big Band Jazz (New York: Oxford University Press, 2004), 168.
} 
1933-36. Other popular sweet jazz stylists who got high marks at the Roof are Art Kassel and Herbie Kay; Indianapolis-born Noble Sissle (one of the few black musicians in the top group) also earned high ratings. These bands appeared for one-night stands (usually on a Sunday). In contrast, many of the lowest rated bands are little-known, local musicians with the highest number of appearances, such as Denny Dutton (seventy-four) and Chic Myers (sixty-seven).

\begin{tabular}{|c|c|c|c|}
\hline Name & Ratings & Dates (1933-36) & \# Perf. \\
\hline \multirow{3}{*}{ Jan Garber } & 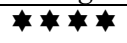 & Apr 14, 1934 & 3 \\
\hline & $\star * * *$ & Dec 28,1934 & \\
\hline & $\star \star \star \star \star ~$ & Feb 23, 1936 & \\
\hline \multirow[t]{2}{*}{ Art Kassel } & $\star \star \star$ & Feb 11, 1934 & 2 \\
\hline & $\star \star \star \star \star ~$ & May 5, 1935 & \\
\hline \multirow[t]{2}{*}{ Herbie Kay } & 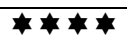 & Nov 5, 1933 & 2 \\
\hline & $\star \star \star$ & Oct 14,1934 & \\
\hline \multirow[t]{2}{*}{ Noble Sissle } & 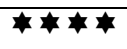 & Feb 4, 1934 & 2 \\
\hline & $\star \star \star$ & June 2,1934 & \\
\hline Charlie Agnew & 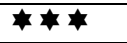 & Mar 25, 1934 & 1 \\
\hline Ralph Bennett & $\star \star \star$ & Nov 19,1933 & 1 \\
\hline Buddy Rogers & $\star \star \star$ & Oct 1,1933 & 1 \\
\hline Henry Busse & $\star * *$ & Feb 18, 1934 & 1 \\
\hline \multirow{3}{*}{ Joe Cappo } & $\star * \star$ & Jan $21-25,1934$ & 32 \\
\hline & $\star * *$ & Mar 27-Apr 8, 1934 & \\
\hline & $\star *$ & Oct 9-Nov 4, 1934 & \\
\hline \multirow[t]{10}{*}{ Slim Lamar } & 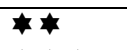 & Oct 4-6, 1933 & 38 \\
\hline & $\star \star \star *$ & Mar 11, 1934 & \\
\hline & $\star * *$ & Jan 9-11, 1935 & \\
\hline & $\star *$ & Feb $12-15,1935$ & \\
\hline & $\star$ & Mar 1, 1935 & \\
\hline & & $\operatorname{Mar} 7,1935$ & \\
\hline & $\star \star \star$ & Sept 20-Oct 2, 1935 & \\
\hline & $\star \star \star$ & Dec $20-24,1935$ & \\
\hline & ** & Jan 28-Feb 9, 1936 & \\
\hline & $\star \star$ & $\operatorname{Mar} 7,1936$ & \\
\hline \multirow[t]{8}{*}{ Louis Lowe } & $\star \star$ & May 9-13, 1934 & 24 \\
\hline & $\star \star$ & Apr 1721,1935 & \\
\hline & $\star \star$ & Apr 28-May 1, 1935 & \\
\hline & $\star \star$ & May $14-15,21-22,1935$ & \\
\hline & $\star \star$ & Oct 21,1935 & \\
\hline & ** & Dec 16, 1935 & \\
\hline & $\star \star \star$ & Apr 28-30, 1936 & \\
\hline & $\star *$ & May $10-15,1936$ & \\
\hline Jack Berry & $\star \star$ & Feb 20-24, 1934 & 2 \\
\hline \multirow[t]{3}{*}{ Percy Carson } & $\star \star$ & Oct $24-27,1933$ & 9 \\
\hline & $\star \star$ & Oct $31-$ Nov 4, 1933 & \\
\hline & $\star *$ & Nov 7-11, 1933 & \\
\hline California Syncopators & $\star \star$ & Nov 30, 1933 & 1 \\
\hline Jack Crawford & $\neq \star$ & Mar 18, 1934 & 1 \\
\hline Johnny Hamp & $\star \star$ & Apr 8,1934 & 2 \\
\hline
\end{tabular}




\begin{tabular}{|c|c|c|c|}
\hline & $\star \star$ & Apr 28, 1934 & \\
\hline Fletcher Henderson & $\star \star$ & Dec 20, 1933 & 1 \\
\hline Ted Mack & $\star \star$ & Oct 7-22, 1933 & 10 \\
\hline Joe McCartney & $\star \star$ & Feb 25, 1934 & 2 \\
\hline & $\star \star$ & Mar 4, 1934 & \\
\hline McKinney's Cotton Pickers & $\star \star$ & Jan 12-20, 1934 & 13 \\
\hline & $\star \star$ & Mar 16-24, 1934 & \\
\hline Bill Moon & $\star \star$ & May 26, 1934 & 5 \\
\hline & $\star \star$ & May 30-June 1, 1934 & \\
\hline & $\star \star$ & June $3-5,1934$ & \\
\hline Louie Panico & $\star \star$ & Oct $28-29,1933$ & 2 \\
\hline Frankie Trumbauer & $\star \star$ & Sept 15-27, 1933 & 8 \\
\hline Zack Whyte & $\star \star$ & Feb 6-7, 1934 & 1 \\
\hline Denny Dutton & $\star$ & Feb 27, 1934 & 74 \\
\hline & $\star$ & May 15-25, 1934 & \\
\hline (as Dutton-Desautelle) & $\star$ & Apr 23-26, 1935 & \\
\hline & & May 3, 1935 & \\
\hline & $\star \star$ & May 8-10, 19,1935 & \\
\hline & $\star \star$ & May 30-June 1, 7, 11, 1935 & \\
\hline & $\star \star$ & Mar 27-April 11, 14-26, 1936 & \\
\hline & $\star$ & May 1-6, 1936 & \\
\hline Earl Newport & $\star \star$ & Dec $1-19,1933$ & 33 \\
\hline & $\star$ & Nov 14-18, 1933 & \\
\hline & $\star$ & Nov 21-29, 1933 & \\
\hline & $\star \star$ & Dec $21,1933-\operatorname{Jan} 10,1934$ & \\
\hline Chic Myers & $\star \star$ & Apr 10-May 8, 1934 & 67 \\
\hline & $\star$ & May 27-29, 1934 & \\
\hline & $\star$ & Feb 11-12, 1936 & \\
\hline & $\star$ & Feb 19-20, 22, 25-Mar 6, 8-25, & \\
\hline & $\star$ & $\begin{array}{l}1936 \\
\text { Mav } 11-30,1936\end{array}$ & \\
\hline & & June 3,1936 & \\
\hline Paul Specht & $\star *$ & Nov 12,1933 & 2 \\
\hline & $\star$ & Apr 22, 1935 & \\
\hline Brown Buddies & $\star$ & Dec 31, 1933 & 1 \\
\hline Red Hufford & $\star$ & Feb 28-Mar 10, 1934 & 11 \\
\hline & $\star$ & Mar 13-14, 1934 & \\
\hline & $\star$ & Jan 30,1936 & \\
\hline Jack Tilson & $\star$ & June 9,1934 & 1 \\
\hline Miller Welch & 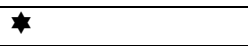 & Feb 10-17, 1934 & 5 \\
\hline "Swing Gates" Jones & - & Feb 2-3, 1934 & 1 \\
\hline Bernie Young & - & Sept 29-30, 1933 & 2 \\
\hline House of David & plain chicken-shit & Apr 1, 1934 & 1 \\
\hline
\end{tabular}

Figure 4. Performers in 1933-34 by star ratings (with cross references to all performances listed on the Door and total performances for 1933-36). 
STRATEGIES OF MANAGEMENT: NEWSPAPER ADS AND ARTICLES FOR 1933-

34

While the Door gives a glimpse of what two people already inside the IRB thought of the music, newspaper articles and advertisements give a sense of how the management of the IRB sought to bring the general public into the Ballroom. This "strategy of management" conflicts with the "strategy of memory" seen on the Door itself. ${ }^{14}$ In the 1930 s the IRB was managed by Tom Devine, who, ironically, wanted less dancing at the Ballroom as he explained in a newspaper interview before the 1933-34 season.

\section{Tom Devine Says Jazz Age is Ended; Roof Prepares for Opening Tonight}

Tom Devine of the Indiana Roof deserted the hustle and bustle characteristic of the reopening of a ballroom for a while yesterday, and tried to visualize the changes that are to take place in the dancing world during the season which the Indiana Roof enters at its opening tonight.

Most important among the changes which Devine offers his dance patrons for the coming season is the installation of facilities for serving 3.2 beverages.

Devine says that he believes this change is fundamentally responsible for the alterations which are taking place in the amusement palaces around the country. Most noticeable among the changes are the new dance tempos and corresponding changes in dance rhythm.

\section{Slow Steps Popular}

Devine predicts a hurried return of the languorous steps popular during the pre-war days. He says the jazz age is a thing of the past as is the idea that dancing is a pastime for only persons between the ages of 18 and 25 years.

He believes that many persons who formerly avoided dance amusement palaces will be regular patrons under his new set up. He says that a great percentage of them may just sit and enjoy the music and entertainment without dancing.

${ }^{14}$ A similar methodology of using newspaper advertisements to study jazz history is used in Anthony J. Bushard, "The Jazz and Blues Club Scene in Kansas City as Portrayed in the Kansas City Call, 1930-1939," University of Kansas, Master's Thesis, 2000. 
With this thought in mind Devine has arranged with Frankie Trumbauer and his orchestra to entertain the Roofs patrons with a concert program once each evening during the dance intermission. He says this program will not interfere with the regular dance schedule.

The Roof will be open for dancing each Friday, Saturday, Sunday, and Wednesday nights. ${ }^{15}$

The idea that Depression marked the end of the "jazz age" of the 1920s is also expressed by Lewis A. Erenberg in Swingin' the Dream: Big Band Jazz and the Rebirth of American Culture. "The crash and the depression brought an abrupt end to the jazz age's cultural outpouring among whites and dramatically transformed the music business both in New York and in the nation as a whole."16 Erenberg observed that one musical reaction to the Depression included the playing of more "sedate" music by bands like Whiteman-an accurate description of the musical culture at the IRB in the early 1930s.

The seemingly contradictory idea of the manager of a dance hall trying to attract people who do not dance may help explain part of Devine's strategy of management. As will be seen below, the newspaper advertisements stress the many non-musical events Devine hosted at the IRB to draw crowds to the Roof. While the Jazz Door memorializes the IRB as a dance palace by listing the band leaders or groups that played there, Devine saw the Ballroom more as an entertainment venue that offered many non-musical events, as well as dance music.

In his interview with the Indianapolis Star before the 1933 season, Devine referenced the end of Prohibition, when he mentioned that the IRB would begin servings of " 3.2 beverages"-beer that is $3.2 \%$ alcohol by weight. Devine believed this was going to transform his customers from active dancers to sedate drinkers who would "just sit and enjoy the music and entertainment without dancing." This did not happen. Although the IRB did experiment with serving alcohol as Prohibition was ending, the IRB eventually became a dry establishment and had a carefully groomed reputation of not offering alcohol to its patrons. Nevertheless, Devine promoted cold beer as part of the opening of the season with Frankie Trumbauer and promoted free beer on November 25th (advertised as "Heidelberg Night" in the heavily German-populated Indianapolis),

${ }^{15}$ Indianapolis Star, September 15, 1933.

${ }^{16}$ Lewis A. Erenberg, Swingin' the Dream: Big Band Jazz and the Rebirth of American Culture (Chicago: Chicago University Press, 1998), 11. 
although Prohibition was not officially repealed until December 5 with the enactment of the Twenty-first amendment. Kelly and Young did not note anything special about these nights. The end of Prohibition, one of the most important changes in US society in 1933, goes unmentioned on the Jazz Door and turned out to be of little consequence at the IRB.

The most important facts the newspaper advertising provides are the varying ticket prices for different bands, which are analogous to the star ratings on the Door (see Figure 5) - they indicate Devine's evaluation of the marketability of the bands. The normal weekday ticket price at the Ballroom in the 1933-34 season given in the newspaper ads was 25\% before 9:00 p.m., with the assumption of a higher price after this time, but such details were not spelled out in the print advertising. The popularity of one-night bands is reflected in ads several weeks before their appearance at the IRB, the increased ticket prices, incentives to purchase tickets before the day of the dance, and added costs to reserve a table.

The IRB also raised prices for holidays and events such as New Years, Christmas, and the Indianapolis 500, but such price increases reflect the demands for a place to celebrate. Tickets were also sold for private events and fundraisers that featured music and dancing, such as the Young Republicans meeting at the end of the 1933-34. Most of these musical events were listed on the Door as well.

Higher Priced Bands

\begin{tabular}{|c|c|c|c|}
\hline Ticket & Table/Couple & Performer & Dates (1933-34) \\
\hline $\begin{array}{l}.85 \mathrm{Adv} \\
1.10 \mathrm{Door}\end{array}$ & 1.00 & Buddy Rogers & Oct 1,1933 \\
\hline $\begin{array}{l}.80 \mathrm{Adv} \\
1.10 \mathrm{door}\end{array}$ & 1.00 & Jan Garber & April 14, 1934 \\
\hline $\begin{array}{l}.55 \mathrm{Adv} \\
.80 \text { Door }\end{array}$ & .75 & Henry Busse & Feb 18, 1934 \\
\hline $\begin{array}{l}.55 \mathrm{Adv} \\
.80 \mathrm{Door}\end{array}$ & .75 & Charlie Agnew & Mar 25, 1934 \\
\hline $\begin{array}{l}.55 \mathrm{Adv} \\
.80 \mathrm{Door}\end{array}$ & .75 & Jack Crawford & Mar 18, 1934 \\
\hline $\begin{array}{l}.55 \mathrm{Adv} \\
.80 \text { Door }\end{array}$ & .75 & Art Kassel & Feb 11, 1934 \\
\hline .55 & .75 & Noble Sissle & Feb 4, 1934 \\
\hline .55 & - & Johnny Hamp & April 8, 1934 \\
\hline $\begin{array}{l}.50 \mathrm{Adv} \\
.75 \text { Door } \\
\end{array}$ & .50 & Herbie Kay & Nov 5, 1933 \\
\hline .50 & - & Frankie Trumbauer & Sept $15-26,1933$ \\
\hline .40 & - & Louis Panico & Oct $28-29,1933$ \\
\hline .40 & - & House of David & Apr 1, 1934 \\
\hline
\end{tabular}




\begin{tabular}{|c|c|c|c|}
\hline \multicolumn{4}{|c|}{ Lower Priced Bands } \\
\hline Ticket & Table/Couple & Performer & Dates (1933-34) \\
\hline $.25(?)$ & - & Bernie Young & Sept 29-30, 1933 \\
\hline $.25(?)$ & - & Slim Lamar & $\begin{array}{l}\text { Oct 4-6, } 1933 \\
\text { Mar 11, } 1934\end{array}$ \\
\hline .25 & - & Ted Mac & Oct 7-22, 1933 \\
\hline .25 & - & Percy Carson & $\begin{array}{l}\text { Oct 24-27, } 1933 \\
\text { Oct 31-Nov 4, } 1933 \\
\text { Nov 7-11, } 1933 \\
\end{array}$ \\
\hline .25 & - & Paul Specht & Nov 12,1933 \\
\hline .25 & - & Ralph Bennett & Nov 19,1933 \\
\hline .25 & - & Earl Newport & Nov 1933-Jan 101934 \\
\hline .25 & - & Fletcher Henderson & Dec 20, 1933 \\
\hline .25 & & Joe Cappo & $\begin{array}{l}\text { Jan } 21-25,1934 \\
\text { Mar 27-Apr 8, } 1934\end{array}$ \\
\hline .25 & - & Miller Welch & Feb 10-17, 1934 \\
\hline .25 & - & McKinney's Cotton Pickers & $\begin{array}{l}\text { Jan } 12-20,1934 \\
\text { Mar } 16-24,1934\end{array}$ \\
\hline .25 & - & Jack Berry & Feb 20-24, 1934 \\
\hline .25 & - & $\begin{array}{l}\text { Zach Whyte } \\
\text { ("Swing Gates" Jones) }\end{array}$ & $\begin{array}{l}\text { Feb 6-7, 1934 } \\
\text { (Feb 2-3, 1934) } \\
\end{array}$ \\
\hline $.25(?)$ & - & Denny Dutton & $\begin{array}{l}\text { Feb 27, 1934 } \\
\text { May 15-25, } 1934\end{array}$ \\
\hline $.25(?)$ & 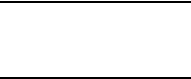 & Joe McCartney & $\begin{array}{l}\text { Feb 25, } 1934 \\
\text { Mar 4, } 1934\end{array}$ \\
\hline $.25(?)$ & - & Red Hufford & $\begin{array}{l}\text { Feb 28-Mar 10, } 1934 \\
\text { Mar 13-14, } 1934\end{array}$ \\
\hline $.25(?)$ & - & Chic Myers & $\begin{array}{l}\text { Apr 10-May 8, } 1934 \\
\text { May 27-29, } 1934\end{array}$ \\
\hline $.25(?)$ & - & Louie Lowe & May 9-13, 1934 \\
\hline $.25(?)$ & - & Bill Moon & $\begin{array}{l}\text { May 26, } 1934 \\
\text { May 30-June 1, } 1934 \\
\text { June 3-5, } 1934\end{array}$ \\
\hline
\end{tabular}

\begin{tabular}{|c|c|c|c|}
\hline \multicolumn{4}{|c|}{ Events and Holidays } \\
\hline Ticket & Table/Couple & Performer & Dates (1933-34) \\
\hline $.85 \mathrm{Adv}$ & \multirow[t]{2}{*}{1.00} & New Year's Eve & \multirow[t]{2}{*}{ Dec 31, 1933} \\
\hline 1.10 Door & & $\begin{array}{l}\text { Harlem High Hatters } \\
\text { (Brown Buddies) }\end{array}$ & \\
\hline $.80 \mathrm{Adv}$ & \multirow[t]{2}{*}{ - } & Variety Club & \multirow[t]{2}{*}{ April 28, 1934} \\
\hline 1.10 Door & & Johnny Hamp & \\
\hline $.55 \mathrm{Adv}$ & \multirow[t]{2}{*}{.50} & Speedway Ball (Indy 500) & \multirow[t]{2}{*}{ May, 28, 1934} \\
\hline .80 Door & & Chic Myers & \\
\hline .40 & - & $\begin{array}{l}\text { Republican Candidates } \\
\text { Jack Tilson }\end{array}$ & June 9,1934 \\
\hline \multirow{3}{*}{$\begin{array}{l}\text { (?-private } \\
\text { event) }\end{array}$} & \multirow[t]{3}{*}{ - } & Thanksgiving & \multirow[t]{3}{*}{ Nov 30, 1933} \\
\hline & & California Syncopators & \\
\hline & & (Mildred Harris Chaplin) & \\
\hline
\end{tabular}

Figure 5. Ticket Prices at the Indiana Roof Ballroom 1933-1934. (?) indicates that the prices were not cited in newspaper advertisements. 
FALL TO WINTER AT THE IRB (1933-34)

It is now possible to present a summary of the 1933-34 season that integrates the ratings on the Door, the advertisements and articles on IRB from the newspapers, along with biographical information on specific musicians. In addition to a general survey of the entire season, two periods in the fall and spring are studied in depth to present a better picture of the day-to-day life at the IRB. When the information on the Door and the ads are compared in the 1933-34 season, the discrepancies between the management's goals and the interests of Kelly and Young as the creators of the Jazz Door can be seen more clearly.

The Door often gives broad spans of dates-making it seem as if the IRB was open every day of the week. The print ads and the articles in the newspapers about the IRB, however, present a more accurate picture of the day-to-day operations of IRB. November 1933 can serve as an example of the typical IRB schedule (see Figure 6). 
Door Information Ticket Prices

\begin{tabular}{|c|c|c|c|}
\hline 8-PERCY CARSON & $\star \star$ & (OCT 31-NOV 4) & .25 \\
\hline 9-HERBIE KAY & $\star \star \star \star *$ & (NOV 5) & $.50 \mathrm{Adv} ; .75$ Door; .50 Table \\
\hline 10-PERCY CARSON & $\star \star$ & (NOV 7-11) & .25 \\
\hline 11-PAUL SPECHT & $\star \star$ & (NOV 12) & .25 \\
\hline 12-EARL NEWPORT & $\star$ & (NOV 14-18) & .25 \\
\hline 13-RALPH BENNETT & $\star \star \star$ & (NOV 19) & .25 \\
\hline 14-EARL NEWPORT & $\star$ & (NOV 21-29) & .25 \\
\hline $\begin{array}{l}\text { 15-CALIFORNIA } \\
\text { SYNCOPATORS }\end{array}$ & $\star \star$ & (NOV 30) & $\begin{array}{l}\text { No price given (private } \\
\text { event) }\end{array}$ \\
\hline
\end{tabular}

\begin{tabular}{|c|c|c|c|c|c|c|}
\hline \multicolumn{7}{|c|}{ November 1933} \\
\hline Sun & Mon & Tues & Wed & Thurs & Fri & Sat \\
\hline & & & $\begin{array}{l}1 \\
\text { Percy Carson } \\
>>>> \\
\text { (Waltz Night) }\end{array}$ & 2 & $\begin{array}{l}3 \\
\text { Percy Carson } \\
\text { >>>> } \\
\text { Ladies Night }\end{array}$ & $\begin{array}{l}4 \\
\text { Percy } \\
\text { Carson } \\
\star \star \\
\end{array}$ \\
\hline $\begin{array}{l}5 \\
\text { Herbie } \\
\text { Kay } \\
\star \star \star \star\end{array}$ & 6 & $\begin{array}{l}7 \\
\text { Percy } \\
\text { Carson } \\
\text { >>>> }\end{array}$ & $\begin{array}{l}8 \\
\text { Percy Carson } \\
>>>> \\
\text { Waltz Night }\end{array}$ & 9 & $\begin{array}{l}10 \\
\text { Percy Carson } \\
\text { >>>> } \\
\text { Ladies Night }\end{array}$ & $\begin{array}{l}11 \\
\text { Percy } \\
\text { Carson } \\
\star \star\end{array}$ \\
\hline $\begin{array}{l}12 \\
\text { Paul } \\
\text { Specht } \\
\star \star\end{array}$ & 13 & $\begin{array}{l}14 \\
\text { Earl } \\
\text { Newport } \\
>>>>\end{array}$ & $\begin{array}{l}15 \\
\text { Earl Newport } \\
>>>> \\
\text { Waltz Night }\end{array}$ & & $\begin{array}{l}17 \\
\text { Earl Newport } \\
\text { >>>> } \\
\text { Ladies Night }\end{array}$ & $\begin{array}{l}18 \\
\text { Earl } \\
\text { Newport } \\
\star\end{array}$ \\
\hline $\begin{array}{l}19 \\
\text { Ralph } \\
\text { Bennet } \\
\star \star \star\end{array}$ & 20 & $\begin{array}{l}21 \\
\text { Earl } \\
\text { Newport } \\
>>>>\end{array}$ & $\begin{array}{l}22 \\
\text { Earl Newport } \\
>>>> \\
\text { Waltz Night }\end{array}$ & 23 & $\begin{array}{l}24 \\
\text { Earl Newport } \\
>>>> \\
\text { (Ladies } \\
\text { Night) } \\
\end{array}$ & $\begin{array}{l}25 \\
\text { Earl } \\
\text { Newport } \\
>>>>\end{array}$ \\
\hline $\begin{array}{l}26 \\
\text { Earl } \\
\text { Newport } \\
\text { >>>> }\end{array}$ & 27 & $\begin{array}{l}28 \\
\text { Earl } \\
\text { Newport } \\
\text { >>>> }\end{array}$ & $\begin{array}{l}29 \\
\text { Earl Newport } \\
\star \\
\text { (Waltz Night) }\end{array}$ & $\begin{array}{l}30 \\
\text { California } \\
\text { Syncopators } \\
\star \star\end{array}$ & & \\
\hline
\end{tabular}

Figure 6. November 1933 at the Indiana Roof Ballroom as listed on the Door and as a calendar. Arrows indicate the continuation a band's engagements (one entry on the Door); star ratings are given for the end of band's engagement. Events in parentheses are not advertised in the newspaper ads, but assumed by the author.

The featured Sunday bandleaders in November included Herbie Kay, Paul Specht, and Ralph Bennett. Specht and Bennett were on the declining side of the popularity they had in the 1920s; newspaper ads give higher prices only for Herbie Kay's band (50\$ advanced ticket, $75 \$$ at the door, and $50 \$$ for a table reservation), indicating that Devine did not see Specht or Bennett as outstanding financial draws. The last Sunday in 
November did not feature a name band-the weekday band played without any advertising promotion.

Herbie Kay's Lucky Strike Orchestra was a highly respected Chicago band most popular in the late 1920s and early 1930s. His band also played at the Avalon Casino on Catalina Island off the Southern California coast, which featured sweet bands, like Jan Garber. ${ }^{17}$ The top rating on the Door may be a testament not only to the band's music, but also to the popularity of Kay's singer at the time, Dorothy Lamour, who was featured prominently in newspaper photos before the band's appearance. Lamour moved to Chicago after winning a beauty pageant in New Orleans in 1931. She sang with Kay for a few years and married him in 1935. The following year Lamour left the band for a career in Hollywood, where she most famously played the love interest of Bob Hope and Bing Crosby in Road to Bali and other Road to... movies in the 1940s. She and Kay divorced in 1939. Specht had been a popular recording artist of the 1920s, but he was on the waning side of his popularity by the time he appeared at the Roof. ${ }^{18}$ Ralph Bennett led The Seven Aces which later grew in size, but confusingly kept its original name, billing themselves as "The Seven Aces, All Eleven of Them.." ${ }^{19}$ Bennett's appearance at the Roof was well received musically with a high rating on the Door, despite the modest ticket price for his appearance.

The weekday bands in November were Percy Carson and Earl Newport; both are given multiple entries on the Door to cover all their appearances. Carson led the orchestra at the Edgewater Beach Hotel in Chicago. He appeared at the Roof a few times in the fall of the 1933-34 season, (although he does not appear in the later seasons recorded on the Door).

\footnotetext{
${ }^{17}$ Berish, “I Dream of Her and Avalon'," 547.

${ }^{18}$ Specht is the author of the hagiographic book, How They Become Name Bands: The Modern Technique of a Danceband Maestro (New York: Fine Arts Publications, 1941). He is described on the title page as "America's Pioneer Dance Orchestra Maestro of Radio." Specht's advice for the budding band leader includes chapters such as "Being Prepared to Make Sacrifices," "Be Friendly," "Be Law-Abiding," and "Be Co-operative." Specht reproduces his correspondence with other popular musicians including Rudy Vallée, Glenn Miller, and Charlie Spivak on how to lead a band.

19 The name "Ralph Bennett" was also used as a pseudonym on American Record Company sides (Banner, Melotone, Oriole, etc.) in the early 1930s. He apparently leased Brunswick the use of his name for these sides and as a result Bennett is listed on numerous recordings on which he did not perform.
} 
In contrast, Newport was a local saxophonist, but little is known of him. ${ }^{20}$ Despite thirty-three appearances at the IRB within three months, his name never appears in Roofs advertising during the winter of 193334: often the IRB did not run ads when Newport performed. Devine clearly did not think the name "Earl Newport" would draw patrons to the IRB. Despite his extensive work during the 1933-34 season and the Roof's constant need for local bands, his name is absent from the Door in later years. It appears that Newport's musical career was short-lived at the IRB.

To draw patrons during the week, Devine used Waltz Night on Wednesday ("Every other dance a waltz") and Ladies Night on Fridays ("Ladies Free, Gentlemen 15ф"). Thus it could cost a couple as little as 15 to hear Earl Newport at the IRB during the week on Ladies Night, but it would cost the same couple as much as $\$ 3.20$ to hear Jan Garber (on April 14).

The ads usually confirm the entries on the Door, but in many cases they provide details omitted from it, and the number and types of these omissions reveal much about the differences between the management and the creators of the Jazz Door. The Door records the appearance of Percy Carson on October 24-27, 1933 (*), during his many weekday jobs at the Roof in the fall, making it seem as if Carson's band was the only event at the Roof. The actual headliner for October 25 in the advertising (the name in the largest type) was Sally Rand, the famous "Fan Dancer." Sally Rand was an act that would attract Devine's new model patron-a customer who would buy a ticket to a ballroom, but who wasn't there to dance.

The differences between the attributions on the Jazz Door and the evidence found in the local newspapers are clearly noticeable on Thanksgiving of 1933 when the Door lists the California Syncopators (*), giving the impression that it was just another night of dancing at the Roof. But apart from the Door itself, there is no documentation of a band called the California Syncopators. Evidence from the newspaper ads clarifies that the Roof was rented by the Beth-El Temple Sisterhood and Men's Club as a charity benefit featuring a floor show revue hosted by the former child movie actress Mildred Harris Chaplin. The California Syncopators provided the music for the entertainments. Harris (1901-44) had been a famous child star of silent movies. At the age of 16 , she married the rising comedian, Charlie Chaplin, who was then 29. The marriage lasted only three years, and with the advent of talking movies her

${ }^{20}$ Schiedt, Jazz State, 63 and 198. 
career waned. She attempted to stay in show business by capitalizing on the Chaplin name with a stage revue. Chaplin's visit to Indianapolis was literally front-page news- her car was repossessed during her engagement at the IRB, which left her stranded and exposed her dire financial situation to the general public. ${ }^{21}$

Another ambiguous entry on the Door occurs in early December; Kelly and Young listed "The Streets of Paris," but indent the listing and do not give it a star rating because it was not a band. As can be seen in the newspaper ads (see Figure 7), it was a tableaux vivant that invited people to witness and participate in "everyday life" in Paris. It was one of the most popular (or scandalous) exhibits of the Chicago Century of Progress Exhibition, which opened in the summer of 1933, and promoted the French capital as a haven for scantily clad women in peep shows and a "colonie nudiste." Kelly and Young note the eight-day event on the Door below the name of Earl Newport in parentheses-downplaying its importance to them.

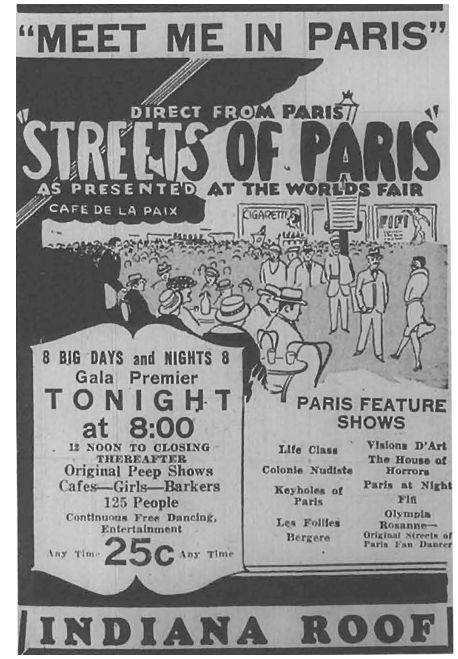

Figure 7. Ad for "Streets of Paris." Indianapolis Star, November 29, 1933.

WINTER TO SPRING AT THE IRB (1933-34)

Mid-March to mid-April is an example of the IRB's spring 1934 schedule (see Figure 8). The IRB had begun to feature battles between the one night headliner and the weekday band on Sunday; these were not listed on the Door, but were an important part of the newspaper advertising.

21 "Show Goes on, But Car Goes Back, so Former Mrs. Chaplin Rides Taxi," Indianapolis Star, December 1, 1933. 
Door Information Ticket Prices

\begin{tabular}{|c|c|c|c|}
\hline 34-SLIM LAMAR & $\star \star \star$ & (Mar. 11) & $.25(?)$ \\
\hline 35-RED HUFFORD & $\star$ & (Mar 13-14) & $.25(?)$ \\
\hline $\begin{array}{l}\text { 36-M'KINNEY'S } \\
\text { COTTON PICKERS }\end{array}$ & $\star \star$ & (Mar 16-24) & .25 \\
\hline 37-JACK CRAWFORD & $\star *$ & $(\operatorname{Mar} 18)$ & $.55 \mathrm{Adv} ; .80$ Door; .55 Table \\
\hline 38-CHARLIE AGNEW & $\star \star \star *$ & (Mar 25) & $.55 \mathrm{Adv} ; .80$ Door; .55 Table \\
\hline 39-JACK [[JOE]] CAPPO & $\star \star \star$ & $\begin{array}{l}\text { (Mar 27- } \\
\text { Apr 8) }\end{array}$ & .25 \\
\hline 40-HOUSE OF DAVID & $\begin{array}{l}\text { plain } \\
\text { chicken-shit }\end{array}$ & (Apr 1) & .40 \\
\hline 41-JOHNNY HAMP & $\star \star$ & (Apr. 8) & .55 \\
\hline 42-CHIC MYERS & $\star \star$ & $\begin{array}{l}\text { (Apr. 10- } \\
\text { May 8) }\end{array}$ & $.25(?)$ \\
\hline 43-JAN GARBER & $\star * \star *$ & (Apr. 14) & $.80 \mathrm{Adv} ; 1.10$ Door; 1.00 Table \\
\hline
\end{tabular}

March/April 1934

\begin{tabular}{|c|c|c|c|c|c|c|}
\hline Sun & Mon & Tues & Wed & Thur & Fri & Sat \\
\hline $\begin{array}{l}11 \\
\text { Slim Lamar }\end{array}$ & 12 & $\begin{array}{l}13 \\
\text { Red Hufford } \\
>>>>> \\
\text { Ladies } \\
\text { Night }\end{array}$ & $\begin{array}{l}14 \\
\text { Red Hufford } \\
\star \\
\text { (Waltz } \\
\text { Night) }\end{array}$ & 15 & $\begin{array}{l}16 \\
\text { McKinney' } \\
\text { s Cotton } \\
\text { Pickers } \\
(\mathrm{MCP})>>>\end{array}$ & $\begin{array}{l}17 \\
\mathrm{MCP}>>>\end{array}$ \\
\hline $\begin{array}{l}18 \\
\text { MCP } \\
\text { vs. Jack } \\
\text { Crawford } \\
\star \star\end{array}$ & 19 & $\begin{array}{l}20 \\
\text { MCP >>> } \\
\text { (Ladies } \\
\text { Night) }\end{array}$ & $\begin{array}{l}21 \\
\text { MCP >>> } \\
\text { (Waltz } \\
\text { Night) }\end{array}$ & 22 & $\begin{array}{l}23 \\
\mathrm{MCP}>>>>\end{array}$ & $\begin{array}{l}24 \\
\mathrm{MCP} \\
\star\end{array}$ \\
\hline $\begin{array}{l}25 \\
\text { Charlie } \\
\text { Agnew } \\
\star \star \star\end{array}$ & 26 & $\begin{array}{l}27 \\
\text { Joe Cappo } \\
>>>> \\
\text { (Ladies } \\
\text { Night) }\end{array}$ & $\begin{array}{l}28 \\
\text { Joe Cappo } \\
\text { >>>> } \\
\text { (Waltz } \\
\text { Night) }\end{array}$ & 29 & $\begin{array}{l}30 \\
\text { Joe Cappo } \\
>>>>\end{array}$ & $\begin{array}{l}31 \\
\text { Joe Cappo } \\
>>>>\end{array}$ \\
\hline $\begin{array}{l}1 \\
\text { Joe Cappo } \\
\text { vs. House of } \\
\text { David } \\
\text { Plain } \\
\text { Chicken- } \\
\text { Shit }\end{array}$ & 2 & $\begin{array}{l}3 \\
\text { Joe Cappo } \\
>>>> \\
\text { (Ladies } \\
\text { Night) }\end{array}$ & $\begin{array}{l}4 \\
\text { Joe Cappo } \\
\text { >>>> } \\
\text { (Waltz } \\
\text { Night) }\end{array}$ & 5 & $\begin{array}{l}6 \\
\text { Joe Cappo } \\
>>>>\end{array}$ & $\begin{array}{l}7 \\
\text { Joe Cappo } \\
\star \star \star\end{array}$ \\
\hline $\begin{array}{l}8 \\
\text { Joe Cappo } \\
\text { vs Johnny } \\
\text { Hamp } \\
\star \star\end{array}$ & 9 & $\begin{array}{l}10 \\
\text { Chic Myers } \\
>>>> \\
\text { Ladies } \\
\text { Night }\end{array}$ & $\begin{array}{l}11 \\
\text { Chic Myers } \\
>>>> \\
\text { (Waltz } \\
\text { Night) }\end{array}$ & 12 & $\begin{array}{l}13 \\
\text { Chic Myers } \\
>>>>\end{array}$ & $\begin{array}{l}14 \\
\text { Jan Garber } \\
\star \star \star\end{array}$ \\
\hline
\end{tabular}

Figure 8. Mid-March to Mid-April at the Indiana Roof Ballroom. Arrows indicate the continuation a band's engagements (one entry on the Door); star ratings are given for the end of band's engagement. MCP=McKinney's Cotton Pickers. Events in parentheses are not advertised in the newspaper ads, but assumed by the author. 
The featured Sunday performers from mid-March to mid-April included Slim Lamar, Jack Crawford, Charlie Agnew, and Johnny Hamp. (The House of David Band is discussed more fully below.) The highlight of the spring (if not of the entire season) was the appearance of Jan Garber on Saturday, April 14. The original "Slim" Lamar was the cornetist Henry E. Lamar, who was popular in the late 1920 s with such novelty songs as "Goofus." ${ }^{22}$ His younger brother Ayars, a saxophonist who led bands at Indiana University, had taken over the band by 1933 and also the nickname "Slim." The Indianapolis newspapers refer to him as Ayars while the Door refers to him as "Slim Lamar." ${ }^{23}$ His Indiana roots explain his frequent appearances at the IRB (thirty-eight in all) as both a onenight performer and as a weekday band; he received the widest variety of responses from Kelly and Young ranging from one to three stars. Jack Crawford was the self-described "Clown Prince of Jazz." He offered an entertainment that was equal doses of sweet dance music and comedy. ${ }^{24}$ He was a popular act, particularly in the Midwest. Charlie Agnew formed his band in 1924 and was popular in Chicago and the Midwest. Radio exposure on shows like The Lucky Strike Magic Carpet propelled him for a while to national recognition and nation-wide tours, but for most of his career he worked in and around Chicago. ${ }^{25}$ Johnny Hamp and the Kentucky Serenaders had a hit song, "Black Bottom," in 1926 (Victor). The group was known simply as Johnny Hamp and his Orchestra by the time they played at the Indiana Roof.

The greatness of Jan Garber is one of the few things Tom Devine and the creators of the Jazz Door agreed on-ticket prices for Garber are consistently among the highest of each season, and he was the only bandleader to achieve multiple four-star ratings on the Door. Garber was born in Indianapolis and was a classically trained violinist before turning to dance music after World War I. He was a master of knowing what audiences wanted; Garber made hundreds of records and numerous film

\footnotetext{
${ }^{22}$ http://www.redhotjazz.com/lamar.html and Jazz The World Forgot, Vol. 2, Yazoo 2025 (2000).

${ }^{23}$ Schiedt, Jazz State, 163-64.

${ }^{24}$ Although sideman Drew Paige was not with Crawford's band when they appeared at the IRB, life on the road with the Crawford band is vividly described in Drew's Blues: A Sideman's Life with the Big Bands (Baton Rouge: Louisiana State University, 1980), 42-43.

${ }^{25}$ Charlie Agnew and His Orchestra On the Radio 1932: Slow But Sure. Sounds of Yester Year CD DSOY736 (2007).
} 
appearances; he was featured on radio so often that he was known as "The Idol of the Airlanes." ${ }^{26}$

The weekday bands during this period were Red Hufford, McKinney's Cotton Pickers, Joe Cappo, and Chic Myers. Hufford and Myers were local musicians whose modest careers were centered in Indianapolis. Marvin "Red" Hufford was a saxophonist from Frankfort, Indiana, who led a band comprised of students from Butler University in the late 1920s. Little is known of his musical career apart from his performances in the Indianapolis area. ${ }^{27}$ Charles "Chic" Myers was also a saxophonist who started his band in the mid 1920s and was active in the city in the 1930s. ${ }^{28}$ In addition to the Roof, he also appeared regularly at the Antlers Hotel in Indianapolis. Myers performed sixty-seven times at the IRB over three seasons (second only to Denny Dutton), yet consistently had the lowest ratings by Kelly and Young-with the exception of his first appearance, every performance was only one star.

The two bands with national reputations that nevertheless played as weekday bands at the IRB were McKinney's Cotton Pickers and Joe Cappo. Between 1927 and 1931, McKinney's Cotton Pickers featured a who's who of early jazz stars including Benny Carter (saxophone and clarinet) and Doc Cheatham (trumpet). The band was given a top rating by Kelly and Young on the First Door in the 1929-30 season (probably as a one-night engagement). The band went into a steep decline after saxophonist and arranger Don Redman left in 1931, eventually disbanding in 1934. The Door provides specific evidence of the band's post-Redman decline. Rather than playing one-night jobs to top ratings at the IRB, McKinney's Cotton Pickers were given two-star ratings for both of their weeklong engagements in the spring of 1934 (January 12-20 and March 16-24). ${ }^{29}$

Joe Cappo lead a band that originated in southern Illinois called the Egyptian Serenaders and they played the sweet dance music popular at the

${ }^{26}$ Charles Garrod, Jan Garber and his Orchestra (Sephyr Hills, FL: Joyce Record Club Publication, 1992). Hindsight Records has produced several Garber collections including Jan Garber and His Orchestra Play 22 Big Band Recordings, compact disc, HOD 403 (1987).

${ }^{27}$ Schiedt, Jazz State, 63, 169, 198, 199.

${ }^{28}$ Schiedt, Jazz State, 63, 159, 163, 197-9.

${ }^{29}$ John Chilton, McKinney's Music: A Bio-Discography of McKinney's Cotton Pickers (London: Bloomsbury Book Shop, 1978). 
IRB. ${ }^{30}$ Cappo appeared three times at the Roof Ballroom in 1934, each time as a weekday band. In the years following his work in Indianapolis, however, Cappo made his way to bigger audiences and larger venues. By the early 1940s his name appeared several times in Billboard magazine, including a full-page ad in July 22, 1944.

The conflicting agendas of Tom Devine's strategy of management and Kelly and Young's strategy of memory collide most clearly on the April 1, 1934, appearance of the House of David Band (in a battle with Cappo), for which the Door gives the memorable entry "plain chicken-shit." ${ }^{1}$ By having Cappo's "Egyptian Serenaders" battle the "House of David," Devine set up a clever Biblical pun on April Fool's Day, which was also Easter Sunday in 1934. The music that night may not have been as epic as the pun.

The Israelite House of David was a Christian cult founded by Benjamin Purnell in 1903. Among their beliefs were a strict adherence to vegetarianism and having the men grow their hair and beards long. By the 1920s the House of David had over 900 members located in Benton Harbor, Michigan. ${ }^{32}$ To entertain his followers, Purnell promoted music of all kinds including choirs, orchestras, bands, and popular music groups. The dance bands grew so popular that the House of David took some of these groups on the road to promote their beliefs and make money for the community. The commune had two touring jazz bands in the 1920s, which were advertised under various names such as "The House of David Band," "The House of David Syncopators," or "The Syncopep Serenaders." They were easily distinguished by their long hair and

\footnotetext{
${ }^{30}$ Joe Cappo's music and memorabilia are housed at Michigan State University. These documents (such as contracts, telegrams, and train schedules) provide detailed information about Cappo and the daily life of a working dance bandleader. An index of the music is at http://staff.lib.msu.edu/blackma/ms/cappo.htm. Finding aids to the other materials are http://museum.msu.edu/s-program/mtap/Collections/cappo.html. See also the author's "Dance Band Leader Joe Cappo and the Collections of his Memorabilia and Music at Michigan State University," Fontes Artis Musicae 60, no. 1 (Spring 2013): 9-16.

${ }^{31}$ The House of David Band, Cappo, and the Easter 1934 job are discussed more fully in the author's "The Israelites, the Egyptians, and 'Plain Chicken-Shit': The 1934 Biblical Battle of the Bands at the Indiana Roof Ballroom," Traces of Indiana and Midwestern History 25, no. 2 (Spring 2013): 12-25.

${ }^{32}$ Christopher Siriano, The House of David, Images of America (Charleston, SC: Arcadia, 2007). They are most famous today for their role in the promotion of baseball; Joel Hawkins and Terry Bertolino, The House of David Baseball Team, Images of America (Charleston, SC: Arcadia, 2000).
} 
beards. ${ }^{33}$ The popularity of the House of David Band as a vaudeville act of the early 1920s led the song writing team of Elmer Schoebel, Billy Meyers, and Irving Mills, to write the 1923 "House of David Blues," which concluded with the line "they play the Barbershop Chord but they never shave!"' ${ }^{34}$ In 1927, Purnell was accused of having sex with a number of young female members of the commune. He died before a final verdict was given in the trial, but the bad publicity forced the bands to stop touring and to perform only around Benton Harbor. ${ }^{35}$

If Devine drew The Streets of Paris, Sally Rand, and Willie Vocalite from the Century of Progress Exhibition, it is possible that he heard the House of David Band there as well. The group had a small booth on the Fair grounds at the 23 rd Street Bridge. ${ }^{36}$

It is shocking to see the words "plain chicken-shit" on the Door since Kelly and Young's creation appears to be a reasonable and objective record of day-to-day life at the IRB-poor musical acts could be given only one star, and in a few cases bands appear with no stars. The first and most obvious conclusion is that the Door's scribes thought the House of David Band really stunk. While this may have been the case, this brazen decree is a reminder that the markings on the Door are not as objective as they seem.

Devine raised ticket prices for the House of David Band, as he had for other Sunday featured performers, but only to $40 \$$ - much less than most other weekend bands in March and April, but higher than the weekday

${ }^{33}$ Some of the details about the House of David Band are courtesy of Tom Meldrim and Keith Howard, personal interviews in Kalamazoo, Michigan on May 13, 2010. See also their essay "House of David-Musical Traditions" at the House of David website http://www.israelitehouseofdavid.com/music.html - Ms53.

${ }^{34}$ The lyrics are given in the Appendix. Although the song has been recorded by dozens of jazz, blues, and folk musicians, there are no known recordings of the House of David Band itself. The best-known recording of "The House of David Blues" may be Fletcher Henderson's (1931).

${ }^{35}$ The Indianapolis appearance may have been part of a possible comeback attempt by the House of David Band following the Chicago World's Fair. The House of David Museum contains a poster for one other public performance of the band at the Knights of Columbus in Owensboro, Kentucky on May 4, 1934, but there is no evidence that the comeback attempt went further than these two engagements. 1934 was most probably the last gasp of the House of David Band beyond Benton Harbor.

${ }^{36} \mathrm{http}: / /$ www.ebooksread.com/authors-eng/ill-century-of-progress-internationalexposition-1933/official-guide--book-of-the-fair-1933-tne/page-17-official-guide-book-of-the-fair-1933-tne.shtml. The House of David Museum in Watervliet, Michigan (http://hodmuseum.tripod.com/) holds a set of music folders which are reinforced with tape reading "House of David/Century of Progress Exhibition." 
bands, like Chic Myers. According to Devine's strategy of management, the House of David Band would attract patrons who would sit and listen to a popular 1920s vaudeville act.

But the House of David Band did not fit into Kelly and Young's judgments of good dance music and their strategy of memory. In a battle of the bands with Cappo (who was proficient in the sweet style that Kelly and Young admired and was on his way to a national reputation), the House of David Band must have seemed hopelessly inferior. Elsewhere on the Door they could downplay Devine's strategy of management (burlesque dancers, robots, faded movie stars, and alcoholic beverages), but they could not ignore the House of David on their record of all the bands that appeared at the IRB.

After the April 1 appearance of the House of David, the weekday bands at the Roof were local bands of little accomplishment: Chic Myer plays most of April and May including several Sundays ( $\star$ or $\star$ ) and Denny Dutton plays most of May ( $)$. The Ballroom also hosted a Memorial Day/Indianapolis 500 dance on May 30. The season ends on June 9 when the IRB is rented for a dance hosted by the Young Republicans.

\section{READING THE DOOR}

The Jazz Door of the Indiana Roof Ballroom is a unique document of jazz history in the early 1930s, but it is not an easy document to read. In the 1980s, when the Indiana Theatre and Roof Ballroom were renovated, a debate ensued about whether to place the Door in the Indiana Historical Society or keep it at the renovated Roof Ballroom. The decision was made to keep the Door at the IRB, but to move it from its storeroom and make it a public monument. ${ }^{37}$ The Jazz Door is currently on display near the stage entrance (so that every performer at the IRB has to walk past it) with a commemorative brass plaque that reads:

In the mid-1930s, the Indiana Roof was among the premier ballrooms in the United States. In those days, when professional criticism of dance bands was very rare, two Indiana Roof employees, JOHN "Jhon" YOUNG and THOMAS J. “Thom"

\footnotetext{
${ }^{37}$ David Mannweiller, “A Place of Honor for Door," Indianapolis Nerws, August 26, 1986. The Door was first discussed by Duncan Scheidt in a series of articles in Jazz Notes, the Newsletter of the Indianapolis Jazz Club in the 1960s. Unfortunately, back issues of Jazz Notes for this period are difficult to locate.
} 
KELLY, established their own rating system and faithfully recorded on this door their own rating for every national, regional, and local band which played the Roof. The INDIANAPOLIS JAZZ CLUB proudly sponsors the preservation of this unique record of music history. November 13, 1986.

By listing every band (good and bad) as well as noting when the Roof was used for other events such as the Flower Show or Hardware Show, Kelly and Young appeared to be creating an honest record of what happened at the Indiana Roof. While it is true that they "faithfully recorded on this door their own rating for every national, regional and local band which played the Roof," some entries recorded on the Jazz Door do not indicate real bands and the entries as a whole are not a complete record of the broad range of entertainments that were presented at the IRB. While the Jazz Door is a fascinating artifact of early jazz history, it is not the entire history of the Indiana Roof Ballroom.

\section{APPENDIX}

Lyrics to "House of David Blues"

A little story that I want to tell, about a certain band that you know well.

An aggregation down in Michigan with a leader man by the name of Ben. They started jazzin' back in ninety two and entertained the folks with music blue. No one has ideas like this leader has, that's why they call it the "Harbor Jazz"

Chorus

Gee! but ain't it grand to hear that band play the House of David Blues.

All the folks in town gather round to see the funny things they do.

When they start to play the women rave and then they start to yell, "At ta boy Dave!" Oh the House of David Band is in demand, when they play the House of David Blues! Now the jazz they play is mighty weird, tho they look like Santa Claus with a beard! A funny thing 'bout the House of Dave, they play the Barbershop Chord but they never shave! 


\section{About the Contributor}

C. Matthew Balensuela is Professor of Music History at DePauw University. His areas of research include early music theory, pedagogy, and jazz and popular music. He is the co-author with David Russell Williams of Music Theory from Boethius to Zarlino: A Bibliography and Guide (Pendragon Press, 2007) which won the Duckles Award from the Music Library Association (2009) and edited and translated the Ars cantus mensurabilis mensurata per modos iuris (University of Nebraska Press, 1994). His scholarship and reviews have appeared in The New Grove Dictionary of Music (Grove Music Online), Acta musicologica, Journal of Musicological Research, and Fontes Artis Musicae; he is the Editor-in-Chief of The Journal of Music History Pedagogy. He earned a BM from the Juilliard School in saxophone performance, MMs in both music history and woodwind performance from Bowling Green State University, and a $\mathrm{PhD}$ in musicology from Indiana University.

The Journal of Jazz Studies (JJS) is published by the Institute of Jazz Studies at the Newark campus of Rutgers, The State University of New Jersey. JJS is hosted online by the Rutgers University Libraries at http://jjs.libraries.rutgers.edu. 